\title{
HUBUNGAN ANTARA STATUS RESEPTOR ESTROGEN, RESEPTOR PROGESTERON DAN HUMAN EPIDERMAL GROWTH FACTOR RECEPTOR 2 DENGAN DERAJAT KEGANASAN KARSINOMA PAYUDARA INVASIF
}

\author{
Muhartono $^{1}$, Soraya Ramanisa ${ }^{2}$, Hanna Mutiara ${ }^{3}$, Ria Janita Riduan ${ }^{4}$
}

\begin{abstract}
Abstrak
Karsinoma payudara invasif (KPI) merupakan keganasan yang berasal dari epitel saluran kelenjar susu dan menginvasi jaringan sekitarnya. Pemeriksaan patologi anatomi biasanya menyertakan derajat keganasan (DKg) dan dilanjutkan dengan pemeriksaan imunohistokimia estrogen receptor (ER), progesterone receptor (PR) dan human epidermal growth factor receptor 2 (HER2) untuk menentukan terapi dan memperkirakan prognosis. Penelitian ini bertujuan untuk mengetahui hubungan status ER, PR, HER-2 dengan DKg pada KPI. Subjek penelitian yang digunakan adalah pasien KPI yang telah diperiksa DKg, status ER, PR dan HER-2 pada tahun 2014-2015 di RSUD Abdoel Moeloek Bandar Lampung. Hasil penelitian menunjukkan DKg low grade sebanyak 13 pasien $(24,1 \%)$, high grade sebanyak 41 pasien (75,9\%), status ER- sebanyak 32 pasien (50,3\%), ER+ sebanyak 22 pasien (40,7\%), PR- sebanyak 32 pasien (59,3\%), PR+ sebanyak $22(40,7 \%)$ dan HER2- sebanyak 33 pasien (61,1\%), HER2+ sebanyak 21 pasien (38,9\%). Hasil uji Chi-Square antara ER dengan DKg nilai $p=0,001$, antara PR dengan DKg nilai $p=0,002$, antara HER2 dengan DKg nilai $p=0,53$. Simpulan, terdapat hubungan antara estrogen receptor dan progesterone receptor dengan derajat keganasan pada karsinoma duktal invasif.
\end{abstract}

Kata Kunci: karsinoma payudara invasif, derajat keganasan, ER, PR, HER2

\begin{abstract}
Invasive breast carcinoma (IBC) is a malignancy derived from the mammary gland duct epithelium and invade surrounding tissues. Anatomic pathology examination usually includes the degree of malignancy (DoM) and continued with immunohistochemical examination of estrogen receptor (ER), progesterone receptor (PR) and human epidermal growth factor receptor 2 (HER2) to determine therapy and predict prognosis. This study aims to determine the relationship status of ER, PR, HER-2 with DoM on IBC. Subjects used were patients who had been examined DoM on IBC, status of ER, PR and HER-2 in the year 2014 to 2015 in hospitals Abdoel Moeloek Bandar Lampung. The results showed low grade DoM as many as 13 patients (24.1\%), high grade total of 41 patients (75.9\%), the status of ER-total of 32 patients (50.3\%), $E R+$ as many as 22 patients (40.7\%), PR-total of 32 patients (59.3\%), PR+ by 22 (40.7\%) and HER2 total of 33 patients (61.1\%), HER2+ as many as 21 patients (38.9\%). Chi-Square test results between the ER with $D K G$ value of $p=0.01$, between PR with DKG value of $p=0.02$, between HER2 with DKG value of $p=0.53$. Conclusion, there is a relationship between the estrogen receptor and progesterone receptor with degrees of malignancy in invasive ductal carcinoma.
\end{abstract}

Key words: invasive breast carcinoma, histological grade, ER, $P R, H E R 2$

Afiliasi Penulis: 1. Bagian Patologi Anatomi, Fakultas Kedokteran Universitas Lampung, 2. Bagian Biologi Molekuler, Fakultas Kedokteran Universitas Lampung, 3. Bagian Parasitologi, Fakultas Kedokteran Universitas Lampung, 4. Bagian Patologi Anatomi, Fakultas Kedokteran Universitas Lampung.

Korespondensi: Muhartono, email: dmuhartono@yahoo.com., Telp/Hp: 081272358340 


\section{PENDAHULUAN}

Karsinoma payudara invasif (KPI) merupakan keganasan yang berasal dari epitel saluran kelenjar payudara dan menginvasi jaringan sekitarnya. Karsinoma payudara invasif adalah salah satu keganasan terbanyak dan memiliki angka kematian cukup tinggi pada wanita. Menurut American Cancer Society (2015), ${ }^{1}$ terdapat 231.840 kasus baru KPI (29\%) dan 40.290 kasus kematian (15\%) di Amerika Serikat. Kasus KPI di negara berkembang telah mencapai lebih dari 580.000 kasus setiap tahun dan kurang lebih 372.000 pasien atau $64 \%$ dari jumlah kasus tersebut meninggal akibat KPI. ${ }^{2}$ Karsinoma payudara invasif di Indonesia menempati urutan kedua setelah kanker serviks. Terdapat 26 kasus per 100.000 penduduk wanita setiap tahun yang menderita KPI. ${ }^{3}$

Salah satu modalitas terapi KPI adalah mastektomi. Pasien yang dilakukan mastektomi selanjunya dilakukan pemeriksaan Patologi Anatomi untuk menentukan diagnosis, metastasis, dan derajat keganasan (DKg). Selanjutnya dilakukan pemeriksaan estrogen receptor (ER), progesterone receptor (PR) dan Human Epidermal Growth Factor Receptor 2 (HER2).

Derajat keganasan dapat memprediksi prognosis dan menentukan terapi, sementara status ER dan PR yang dapat menentukan terapi hormonal ${ }^{4}$ dan memprediksi prognosis KPI. ${ }^{5}$ Selain status hormonal, terdapat pula peranan HER2 yang penting dalam pertumbuhan, proliferasi dan diferensiasi sel. ${ }^{6,7}$ Status ekspresi HER2 penting untuk mengetahui prognosis, prediksi, dan terapi kanker payudara. ${ }^{8}$ Penelitian ini bertujuan untuk mengetahui hubungan antara $E R, P R$, HER2 dengan DKg pada KPI di RSUD Abdoel
Moeloek Bandar Lampung.

\section{METODE}

Penelitian ini adalah penelitian analitik. Pasien yang didiagnosis kanker payudara dilakukan mastektomi. Massa tumor dilakukan pemeriksaan histopatologi untuk menentukan diagnosis dan DKg, selanjutnya dilakukan pemeriksaan imunohistokimia (IHC) ER, PR dan HER2. Pasien KPI adalah pasien yang terdaftar dalam rekam medis pada tahun 2014-2015 di RS Pendidikan Utama Hi Abdul Moeloek/FK Unila. Didapatkan 54 orang yang memenuhi kriteria. Variabel terikat pemeriksaan adalah DKg dan variabel tergantung ER, PR dan HER2. Dalam penelitian ini nomor persetujuan etik penelitian yaitu No. 2482/UN26/8/DT/2015.

\section{HASIL DAN PEMBAHASAN}

Dari data penelitian berdasarkan distribusi kelompok usia menunjukkan bahwa wanita penderita kanker payudara terbanyak ditemukan pada usia 41-50 tahun yaitu sebanyak 25 orang (46,3\%). Distribusi frekuensi status ER terdapat 32 orang (59,3\%) yang memiliki status ER- dan 22 orang $(40,7 \%)$ memiliki status ER+. Distribusi frekuensi status PR diatas menunjukkan bahwa terdapat 32 orang $(59,3 \%)$ yang memiliki status PR- dan 22 orang $(40,7 \%)$ yang memiliki status PR+. Distribusi frekuensi status HER2 diatas terdapat 33 orang $(61,1 \%)$ yang memiliki status HER2- dan 20 orang $(38,9 \%)$ memiliki status HER2+.Data derajat keganasan terdapat 13 orang $(24,1 \%)$ yang tergolong low grade, sedangkan 41 orang $(75,9 \%)$ tergolong high grade. Karakteristik pasien KPI tersaji pada tabel 1. 
Tabel 1. Karakteristik Pasien Kanker Payudara Invasif

\begin{tabular}{ccc}
\hline Karakteristik & Frekuensi (n) & $\begin{array}{c}\text { Persentase } \\
\text { (\%) }\end{array}$ \\
\hline Umur (tahun) & & \\
$21-30$ & & \\
$31-40$ & 1 & $1,9 \%$ \\
$41-50$ & 11 & $20,4 \%$ \\
$51-60$ & 25 & $46,3 \%$ \\
$61-70$ & 12 & $22,2 \%$ \\
Estrogen & 5 & $9,3 \%$ \\
Receptor & & \\
Negatif & 32 & $59,3 \%$ \\
Positif & 22 & $40,7 \%$ \\
Progesteron & & \\
Receptor & 32 & $59,3 \%$ \\
Negatif & 22 & $40,7 \%$ \\
Positif & & \\
HER-2 & 33 & $61,1 \%$ \\
Negatif & 21 & $38,9 \%$ \\
Positif & & \\
Derajat & 13 & $24,1 \%$ \\
Keganasan & 41 & $75,9 \%$ \\
Low grade & & \\
High grade & &
\end{tabular}

Hubungan antara ER dengan DKg tersaji pada tabel 2. Berdasarkan distribusi frekuensi hubungan antara status reseptor estrogen dengan derajat keganasan pada tabel 10 dapat diketahui bahwa terdapat 2 orang yang memiliki status ER- termasuk low grade, sedangkan 30 orang yang memiliki status ERtermasuk high grade. Selain itu pada tabel tersebut juga menunjukkan bahwa 11 orang yang memiliki status ER+ termasuk derajat 2, sedangkan 11 orang yang memiliki status ER+ termasuk high grade. Berdasarkan hasil uji analisis Chi square melalui Tabel 10 juga menunjukkan bahwa penggabungan sel dengan angka kemaknaan atau $\alpha=0,05$ didapat $p$-value sebesar $0,000(p-$ value $<\alpha)$. Hal tersebut menunjukkan bahwa terdapat hubungan yang bermakna antara status ER dengan Dkg pada KPI, seperti yang tersaji pada tabel 2 .

Tabel 2. Hubungan Status Estrogen receptor dengan Derajat Keganasan

\begin{tabular}{|c|c|c|c|}
\hline \multirow{2}{*}{$\begin{array}{l}\text { Reseptor } \\
\text { Estrogen }\end{array}$} & \multicolumn{2}{|c|}{$\begin{array}{c}\text { Derajat keganasan } p- \\
\text { value }\end{array}$} & \multirow{2}{*}{$\mathbf{P}$} \\
\hline & Low grade & $\begin{array}{l}\text { High } \\
\text { Grade }\end{array}$ & \\
\hline Negatif & 2 & 30 & \multirow{2}{*}{0,001} \\
\hline Positif & 11 & 11 & \\
\hline
\end{tabular}

Hubungan antara status PR dengan DKg tersaji pada tabel 3. Berdasarkan distribusi frekuensi hubungan antara status PR dengan DKg pada tabel dapat diketahui bahwa 3 orang yang memiliki status PR- termasuk low grade, sedangkan 29 orang yang memiliki status PR- termasuk high grade. Selain itu pada tabel tersebut juga menunjukkan bahwa 10 orang yang memiliki status PR+ termasuk low grade, sedangkan 12 orang yang memiliki status PR+ termasuk high grade. Berdasarkan hasil uji analisis Chi square didapat nilai $p$ sebesar $\quad 0,002 \quad(p$-value $<\alpha)$ Terdapat hubungan yang bermakna antara status PR dengan DKg pada KPI.

Tabel 3. Hubungan Status Progesterone Receptor dengan Derajat Keganasan

\begin{tabular}{lccc}
\hline \multirow{2}{*}{$\begin{array}{c}\text { Reseptor } \\
\text { Progesteron }\end{array}$} & \multicolumn{2}{c}{$\begin{array}{c}\text { Derajat keganasan } \boldsymbol{p}- \\
\text { value }\end{array}$} & P \\
\cline { 2 - 3 } & Low grade & $\begin{array}{c}\text { High } \\
\text { Grade }\end{array}$ & \\
\hline Negatif & 3 & 29 & 0,002 \\
Positif & 10 & 12 & \\
\hline
\end{tabular}

Hubungan antara status HER2 dengan DKg tersaji pada tabel 4. Berdasarkan distribusi frekuensi hubungan antara status HER2 dengan DKg pada Tabel 12 dapat diketahui bahwa 7 orang yangmemiliki status HER2 - termasuk low grade, sedangkan 26 orang yang memiliki status HER2- termasuk high grade. Selain itu pada tabel tersebut juga menunjukkan bahwa 6 orang yang memiliki status HER2+ termasuk low grade, sedangkan 15 orang yang memiliki status HER2+ termasuk high grade. Berdasarkan hasil uji analisis Chi square didapat nilai $p$ sebesar 0,53 $(p-$ value $<\alpha)$. Tidak terdapat hubungan yang bermakna antara status HER2 dengan DKg pada KPI. 
Tabel 4. Hubungan Status HER2 dengan Derajat Keganasan

\begin{tabular}{lccc}
\hline \multirow{1}{*}{ HER-2 } & \multicolumn{2}{c}{$\begin{array}{c}\text { Derajat keganasan } \boldsymbol{p} \text { - } \\
\text { value }\end{array}$} & P \\
& Low grade & High Grade & \\
\hline Negatif & 7 & 26 & 0 \\
Positif & 6 & 25 & 0,53 \\
\hline
\end{tabular}

Data penelitian ini menunjukkan bahwa pada rentang usia 41-50 tahun merupakan kelompok usia yang paling banyak terjadi KPI. Hasil ini sesuai dengan Rasjidi \& Hartanto $(2009)^{9}$ yang menyatakan bahwa insiden puncak kanker payudara terjadi pada usia 4050 tahun. Windarti $(2014)^{10}$ menyatakan bahwa kanker payudara ditemukan lebih banyak pada usia lebih dari 45 tahun dengan presentase sebesar 53,3\%. Menurut Ayadi (2008), ${ }^{8}$ kanker payudara banyak ditemukan pada usia lebih dari 45 tahun dengan persentase sebesar $60,6 \%$. Pada usia tersebut, wanita memasuki usia menopause, sehingga kadar estrogen dan progesteron mulai menurun begitu juga ER dan PR, akibatnya pada saat yang sama pasien tersebut tidak dapat menerima respon hormonal. ${ }^{11,12}$

Berdasarkan hasil penelitian didapatkan bahwa distribusi frekuensi jumlah pasien kanker payudara yang memiliki status ERmerupakan status ER yang terbanyak sebanyak 32 orang $(59,3)$. Penelitian ini sejalan dengan penelitian Hussain et al. (2011) $)^{13}$ yang menunjukkan bahwa status ERmerupakan status terbanyak dengan presentase $56,2 \%$. Rosai $(2004)^{14}$ menyatakan bahwa sekitar $80 \%$ kanker pada wanita berusia $>45$ tahun mepunyai ER-. Pada usia menopause terjadi penurunan kadar hormon estrogen sehingga hal tersebut menyebabkan penurunan pada reseptor estrogen. ${ }^{12}$

Berdasarkan hasil penelitian didapatkan data status PR yang terbanyak adalah PRyaitu masing-masing sebanyak 33 orang. Penelitian ini didukung oleh penelitian Lari \&
Kuerer $(2011)^{15}$ yang menyatakan bahwa ekspresi dari PR sangat kuat ketergantungannya dengan keberadaan ER. Penelitian Aryandono et al. (2006) $)^{5}$ menunjukkan bahwa status PR- lebih banyak dengan presentase sebesar $51,5 \%$. Penelitian Hussain et al. (2011) ${ }^{13}$ yang menunjukkan bahwa status PR -lebih banyak dibandingkan $\mathrm{PR}+$ dengan presentase $73 \%$. Sesuai dengan teori bahwa tidak adanya PR berkaitan dengan usia menopause yang terjadi penurunan kadar hormon progesteron sehingga hal tersebut menyebabkan penurunan pada PR (Baziad et al.,1997). ${ }^{12}$

Berdasarkan hasil penelitian didapatkan distribusi frekuensi status HER2 menunjukkan bahwa status HER2- lebih banyak yaitu sebanyak 33 pasien. Hal ini sejalan dengan penelitian yang dilakukan oleh Ayadi et al. $(2008)^{8}$ menunjukkan bahwa status HER2lebih banyak dengan presentase sebesar $81,9 \%$. Penelitian ini juga sejalan dengan penelitian Hussain et al. (2011) ${ }^{13}$ yang menunjukkan bahwa status HER2- lebih banyak dibandingkan HER2+ dengan presentase $69,4 \%$. Berdasarkan teori protein ini berperan sebagai antena yang menerima sinyal untuk membiakan sel kanker dengan cepat dan mematikan. Kurang lebih pada 20\%-25\% perempuan dengan kanker payudara terdapat HER2. Diperkirakan hanya satu dari empat hingga lima pasien dengan kanker payudara tahap akhir memiliki HER $2+.{ }^{16}$

Berdasarkan hasil penelitian didapatkan bahwa derajat keganasan terbanyak adalah high grade yaitu sebanyak 41 (75,9\%). Hal ini disebabkan oleh karena banyak pasien datang berobat sudah dalam derajat yang tinggi hal ini dikarenakan oleh beberapa faktor antara lain pengetahuan yang rendah/ketidaktahuan 
penderita, rasa malu, rasa takut dioperasi, faktor jarak atau geografis dan masalah sosial ekonomi. ${ }^{17}$

Berdasarkan data yang diperoleh didapatkan hasil bahwa terdapat hubungan status ER dengan derajat keganasan kanker payudara, hubungan bersifat terbalik yaitu apabila status ER- maka akan terjadi peningkatan derajat keganasan pada penderita kanker payudara, begitupula sebaliknya jika status ER+ maka akan terjadi penurunan dari derajat keganasan dari pasien kanker payudara. Pendapat ini didukung oleh Rosai (2004), ${ }^{14}$ yang menyatakan bahwa adanya ER berhubungan secara signifikan dengan derajat inti yang tinggi dan derajat histopatologi yang rendah, tidak adanya nekrosis, dan usia pasien yang lebih tua. Penelitian ini sejalan dengan penelitian Dunwalld et al. (2007) ${ }^{18}$ bahwa kanker payudara dengan ER positif mempunyai resiko mortalitas lebih rendah dibandingkan ER -, serta penelitian Faheem et al. (2012) ${ }^{19}$ bahwa status ER- berkaitan dengan prognosis yang buruk. Berdasarkan penelitian Ratnatunga \& Liyanapathirana (2007) ${ }^{20}$ menunjukkan bahwa terdapat hubungan yang signifikan antara status ER dengan derajat keganasan yaitu hubungan antara keduanya saling berkebalikan dengan nilai p-value 0,0001. Menurut penelitian Noorasmaliza et al. $(2014)^{21}$ mengatakan bahwa status ERmemiliki hubungan yang signifikan terhadap derajat 3 dengan nilai p-value 0,014. Mekanisme proses karsinogenesis pada kanker payudara dapat terjadi melalui ikatan estrogen pada ER, menstimulasi proliferasi sel-sel payudara yang menimbulkan peningkatan pembelahan sel dan replikasi DNA yang menimbulkan mutasi, dan metabolisme estrogen memproduksi limbah yang toksik terhadap gen dan metabolit yang menyebabkan mutasi. Kedua proses akan menyebabkan inisiasi, promosi, dan proses karsinogenesis (Yager \& Davidson, 2006). ${ }^{22}$

Berdasarkan data hasil penelitian didapatkan bahwa terdapatnya hubungan status PR dengan derajat keganasan, hubungan bersifat terbalik yaitu apabila status PR- maka akan terjadi peningkatan derajat keganasan pada penderita kanker payudara, begitupula sebaliknya apabila status $\mathrm{PR}+$ maka akan terjadi penurunan dari derajat keganasan pada pasien kanker payudara. Penelitian ini didukung oleh penelitian Ratnatunga \& Liyanapathirana (2007) ${ }^{20}$ yang mengatakan bahwa terdapat hubungan yang signifikan antara status PR dengan derajat keganasan yaitu hubungan tersebut saling berkebalikan dengan nilai $p$-value sebesar 0,0001 . Penelitian ini sejalan dengan penelitian Ellis et al. (2003) ${ }^{23}$ bahwa kanker payudara dengan status PR positif mempunyai respon yang lebih bagus terhadap terapi hormonal serta menunjukkan prognosis yang lebih baik dibandingkan status PR-. Selain itu tumor negatif ganda ER-/PR-sekitar $85 \%$ nya merupakan kanker payudara derajat 3 atau differensiasi buruk dan dihubungkan dengan tingkat rekurensi tinggi, ketahanan yang rendah, serta tidak responsif terhadap terapi hormonal. Sementara untuk kelompok yang positif tunggal, ER+/PR- sebanyak 12\%-17\% dan ER-/PR+ sebanyak 1-2\%. Ini dapat dilihat bahwa pasien kanker payudara dengan PRlebih berpengaruh dengan derajat histopatologi yang tinggi, prognosis yang buruk, dan ukuran tumor yang besar.

Reseptor progesteron adalah gen yang diregulasi oleh estrogen, karena itu ekspresinya mengindikasikan adanya jalur ER yang sedang aktif. ${ }^{23}$ Reseptor progesteron 
berperan penting dalam mengetahui pertumbuhan sel kanker payudara hal ini disebabkan oleh karena pada kanker payudara terjadi ketidakseimbangan antara rasio isoform protein PR yaitu PRA dan PRB yang memiliki kapasitas berbeda dalam mengaktifkan gen target yang didominasi oleh PRA. ${ }^{24}$ Meskipun progesteron bukan merupakan agen karsinogen, tetapi progesteron bisa menjadi target ampuh cocarcinogen tertentu untuk menginduksi terjadinya kanker payudara baik dari virus/agen kimia. ${ }^{25}$

Berdasarkan penelitian yang telah dilakukan didapatkan hasil bahwa hubungan status HER2 dengan derajat keganasan bersifat lurus yaitu bila status HER2+ maka akan terjadi peningkatan derajat keganasan pada penderita kanker payudara, begitupula sebaliknya jika status HER2 - maka akan terjadi penurunan dari derajat keganasan dari pasien kanker payudara, namun pada penelitian ini tidak didapatkan hubungan yang bermakna. Hal ini sejalan dengan penelitian Ratnatunga \& Liyanapathirana $(2007)^{20}$ yang mengatakan bahwa tidak terdapat hubungan yang signifikan antara status HER2 dengan derajat keganasan dengan nilai $p$-value sebesar 0,331. Hal tersebut juga diperkuat oleh penelitian Homaei et al. (2006) ${ }^{26}$ yang menunjukkan bahwa tidak ada hubungan yang signifikan antara status HER2 dengan derajat keganasan kanker payudara. Hal ini dapat disebabkan oleh karena amplifikasi gen HER2 terdeteksi hanya pada sekitar 20\%-25\% dari kasus kanker payudara, sehingga pada saat dilakukan pemeriksaan gen HER2 tersebut tidak dapat terdeteksi. ${ }^{16}$

Tidak ditemukannya hubungan antara ekspresi HER-2 dengan derajat keganasan pada kanker payudara dapat disebabkan oleh adanya mutasi yang lain selain dari gen HER-2 (protoonkogen) yang menyebabkan terjadinya kanker payudara. Salah satu penyebab terjadinya kanker adalah akibat dari terganggunya empat kelompok gen pengatur regulasi normal, baik itu gangguan pada gen yang merangsang pertumbuhan protoonkogen, penghambatan tumor supresor gen, regulasi terhadap apoptosis (programmed cell death) dan gen yang melibatkan DNA repair. ${ }^{27}$ Kesemua jalur di atas merupakan target utama terhadap kerusakan genetik, tidak hanya terjadi pada satu mutasi gen HER2 saja melainkan dapat melalui berbagai mutasi yang melibatkan gen lain atau mutasi yang terjadi secara bersamaan. Seperti contohnya kerusakan gen pada tumor suppressor gen (P53, RB1, MSH2, MLH1) atau kerusakan pada gen DNA repair (bcl-2) atau adanya mutasi pada lebih dari satu gen, sehingga semua mekanisme terjadinya mutasi gen tersebut akan mampu meningkatkan progresifitas kanker payudara dan memberikan manifestasi klinis pada derajat keganasannya. Hal ini tidak sejalan dengan Chabner \& Longo (2011) ${ }^{16}$ bahwa pasien kanker payudara HER2+ berhubungan dengan differensiasi buruk, keganasan tumor yang lebih tinggi, resistensi terhadap terapi, kekambuhan yang tinggi, insiden yang lebih tinggi dari metastasis otak, prognosis buruk, presentase sel yang berproliferasi lebih tinggi, aneuploid DNA, dan reseptor hormonal yang lebih sedikit (reseptor estrogen dan reseptor progesteron).

\section{SIMPULAN}

Terdapat hubungan status estrogen receptor (ER) dengan derajat keganasan pada penderita kanker payudara; Terdapat hubungan status progesteron receptor (PR) 
dengan derajat keganasan pada penderita kanker payudara. Terdapat hubungan status
HER-2 dengan derajat keganasan pada penderita kanker payudara.

\section{DAFTAR RUJUKAN}

1. American Cancer Society. 2015. Cancer Facts \& Figures 2015. Atlanta: American Cancer Society.

2. Suryaningsih E, Sukosa B. 2009. Kupas Tuntas Kanker Payudara. Yogyakarta: Paradigma Indonesia.

3. Ibrahim R. 2008. Penanganan Kanker Stadium Lanjut. Jakarta: PT. Rineka Cipta.

4. Davey P. 2006. Medicine At a Glance. Oxford: Blackwell Publishing Ltd.

5. Aryandono T, Harijadi, Soeripto. 2006. Hormone Receptor Status of Operable Breast Cancers in Indonesia: Correlation with Other Prognostic Factors and Survival. Asian Pacific J Cancer Prev. 7(1): 321-324.

6. Gray MJ, Gallick GE. 2010. The Role of Oncogene Activation in Tumor Progression. Mechanisms of Oncogenesis. USA: Springer.

7. Grushko TA, Olopade OI. 2008. Genetic markers in breast tumors with hereditary predisposition. Principle of Molecular Oncology. $3^{\text {rd }}$ Edition. New Jersey: Humana Press.

8. Ayadi L, Khabir A, Amouri H, Karray S, Dammak A, Guermazi M., et al. 2008. Correlation of HER-2 over-expression with clinicopathological parameters in Tunisian breast carcinoma. World J Surg Oncol. 6(1):1-8.

9. Rasjidi I, Hartanto A. 2009. Kanker Payudara. Dalam: Deteksi Dini dan Pencegahan Kanker Pada Wanita. Jakarta: Sagung Seto.

10.Windarti I. 2014. Characteristic of Breast Cancer In Young Women in H. Abdul Moeloek Hospital Bandar Lampung. JUKE. 4(7):131-135.

11.Sadhana, Udadi. 2006. Kanker Payudara Wanita: Ekspresi Reseptor Estrogen, Reseptor Progesteron, dan HER-2. Diakses pada tanggal
$10 \quad$ November $2015 \quad$ dari

http://www.m3undip.org.

12.Baziad A, Santoso BI, Josoprawiro MJ. 1997. Terapi hormone pengganti (THP) dan sindroma urogenital Dalam: Baziad A. Affandi B. Panduan Menopause. Edisi pertama. Jakarta: POGI/PERMI.

13.Hussain GA, Adhraei MA, Kasim A. 2011. Correlations of Hormone Receptors (ER and PR), Her-2/neu and p53 Expression in Breast Ductal Carcinoma Among Yemeni Woman. The Open Cancer Immunolog J. 4(1): 1-9.

14.Rosai J. 2004. Breast. Dalam: Rosai and Ackerman's Surgical Pathology, $10^{\text {th }}$ ed. Philadelphia: Elsevier.

15.Lari SA, Kuerer HM. 2011. Review: biological markers in DCIS and risk of breast recurrence: a systemetic review. J Cancer. 24(2):232-61.

16.Chabner BA, Longo DL. 2011. Cancer Chemotherapy and Biotherapy: Principles and Practice. Philadelphia: Lippincott.

17.Rahman A, Sampepajung D, Hamdani W. 2011. Hubungan Ekspresi HER-2/neu dan Hormonal Reseptor dengan Grading Histopatologi pada Penderita Kanker Payudara Wanita Usia Muda [skripsi]. Makassar: Universitas Hasanuddin.

18.Dunnwald LK, Rossing MA, Li Cl. 2007. Hormone Receptor Status, Tumor Characteristics, and Prognosis: A Prospective Cohort of Breast Cancer Patients. Breast Cancer Res. 9(1):1-10.

19.Faheem M, Mahmood H, Khurram M, Qasim U, Irfan J. 2012. Estrogen Receptor, Progesteron Receptor, and Her-2 Neu Positivity and It's Association with Tumour Characteristics and Menopausal Status in Breast Cancer Cohort From Northern Pakistan. Ecancer Med Science. 6(1):283. 
20.Ratnatunga N, Liyanapathirana L. 2007. Hormone receptor expression and Her-2/neu amplification in breast carcinoma in a cohort of Sri Lankans. Ceylon Med J. 52(4): 133-6.

21.Noorasmaliza, Siti A, Reena, Meor Z, Wan A, Mohan N, et al. 2014. Estrogen ReceptorNegative Breast Ductal Carcinoma: Clinicopathological Features and Mib-1 (Ki-67) Proliferative Index Association. PlosONE.9(2):e89172.

22.Yager JD, Davidson NE. 2006. Mechanisms of Disease, Estrogen Carcinogenesis in Breast Cancer. New England J Med; 354(3):271-79.

23.Ellis IO, Schnitt SJ, Sastre GX. 2003. Invasive Breast Carcinoma in World Health Organization Classification of Tumors Pathology \& Genetics Tumors of the Breast and Female Genital Organs. Lyon: IARC Press.
24. Mote P, Bartow S, Tran N, Clarke C. 2002. Loss of Co-ordinate expression of progesterone receptors $A$ and $B$ is an early event in breast carcinogenesis. Breast Cancer Res Treat. 72(2): 163-72.

25. Malley O, Bert W, Birnbaumer L. 1978. Receptors and Hormone Action. New York: Academic Press.

26. Homaei S, Ghavam N, Shafiri N, Taghizadeh K, Torshizi S, Ghafarzadegan K. 2006. Evaluation of the relationship between human epidermal growth factor receptor-2/neu (c-erb-2) amplification and pathologic grading in patients with breast cancer. Saudi Med J. 27(12):1810-4.

27.Kumar V, Cotran RS, Robbins SL. 2007. Buku Ajar Patologi Edisi ke-7. Jakarta: EGC. 